\title{
Impact of Climate Change on Human Health
}

\author{
Jinky Leilanie DP. Lu
}

Institute of Health Policy and Development Studies, National Institutes of Health, University of the Philippines Manila

\begin{abstract}
Data trends show that climate is changing and several researches have shown the adverse effects of climate change to human health. This review presents how climate change affects human health. Climate change can influence the nature and severity of climate-related natural disasters such as flooding and drought, hence, increasing the rate of mortality and morbidity among human population. Climate change can also increase the likelihood of infection in humans by way of affecting the transmission of infectious diseases. Climateinduced food insecurity is also one of the consequences of climate change and this may eventually result in malnutrition and famine. There are both direct and indirect consequences of climate change to human health. First, the direct health impacts such as injuries and deaths associated with climateinduced natural disasters, and second, the indirect health impacts such as food insecurity, contaminated source of water, and increased incidence of diseases.
\end{abstract}

Key Words: climate change, human health, environmental health, pollution

\section{Introduction}

For a sustainable and viable health condition of the human population, certain factors must be ensured, such as clean air, safe water, safe and sufficient supply of food, and tolerable temperature. ${ }^{1}$ Worldwide, it has been shown that climate and its variability can affect the prevalence and incidence of diseases and other human health consequences. This is based on research findings that climate can alter the transmission of diseases, agricultural productivity, and quality and quantity of food, water, and air, all of which, ultimately affecting human health. ${ }^{2}$

Overall, climate change has caused devastating effects on survival, health, and safety of human societies. In 2000, 5.5 million disability adjusted life years (DALYs) were recorded due to climate change. ${ }^{3}$ Illnesses and disabilities arise from many factors such as skin cancer, dengue, asthma,

Corresponding author: Jinky Leilanie DP. Lu, PhD

Institute of Health Policy and Development Studies

National Institutes of Health

University of the Philippines Manila

623 Pedro Gil St. Ermita, Manila 1000 Philippines

Telephone: +632 5284041

Email: jinky_lu@yahoo.com and malaria which are projected to increase due to climate change. Certain parasitic and microbiological infections such as schistosomiasis, fascioliasis, alveolar echinococcosis, Leishmaniasis, Lyme borreliosis, tick-borne encephalitis, and hantavirus infections have been on the rise with climate change. 3,4 Other health consequences include thermal stress, aeroallergens, and malnutrition. ${ }^{1,5-6}$

Air pollution is another problem that has been associated with climate change. ${ }^{7-10}$ Several of the air pollutants and greenhouse gases interact physically and chemically in the ambient air and atmosphere causing adverse environmental impacts manifesting in climate change in the long run. ${ }^{11}$ These greenhouse gases and air pollutants are substantially attributed to human activities. As a corollary, Oreskes et al., noted that human activities cause the significant increase in global temperature. ${ }^{12}$

This study was done as a review to further understand and elucidate the implications of climate change to human health. It aims to present the linkages of climate change to increased concentrations of air pollutants and emergence and re-emergence of infectious diseases, consequently, affecting human health. The objective of the study is to present how climate change affects human health. Specific objectives are as follows:

a. To identify the human-generated causes of climate change;

b. To study the different pathways how climate change affects human health; and

c. To discuss the climate-related health impacts.

Mainstreaming of climate change in the Philippines has not yet been established despite the high vulnerability to climate hazards and risks, including natural disasters in the country. ${ }^{13}$ (Figure 1).

The study discusses the direct and indirect health impacts of climate change. Environmental pollutants are also discussed by sector. This study intends to present available Philippine data on climate change in the Philippines as well as health impacts based on local sources. The data presented in this study could be part and parcel of the management of health effects of climate change in the Philippines. With regards infectious diseases, particularly the transmission patterns and climate-sensitivity of the vectors/hosts of diseases are suggested for future studies. 


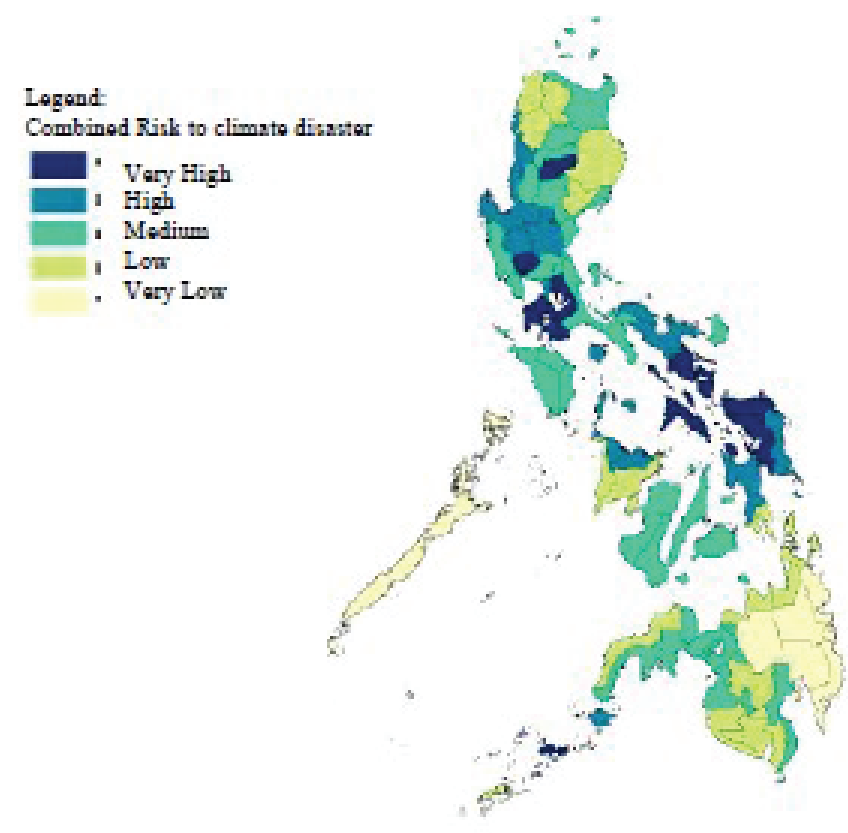

Figure 1. Combined Risk to Climate Disaster. Source: Manila Observatory and DENR (http://www.observatory.ph/vm/ findings.html).

\section{Methods}

The study is a review of climate change and its effect on human health. Data were gathered from national and international sources. Extensive and exhaustive reviews on literature, articles, and other data were done.

Figure 2 shows a simplified procedure in assessing the potential health impacts of climate change. Climate change is mainly caused by greenhouse gas accumulation affecting the environmental systems vis-a-vis the human health loop.

\section{Presentation of Data Gathered}

\section{Sources of Greenhouse Gases (by sector)}

As for sources of greenhouse gases, the energy and transportation sector accounts for the highest percentage of worldwide emission of greenhouse gases at about $60 \%$. This is followed by land use change at $18.2 \%$, and agriculture at $13.5 \%$. Of the all the greenhouse gases emitted, carbon dioxide contributes the largest at $77 \%$, followed by methane $(14 \%)$ and then nitrous oxide $(8 \%)$.

\section{Greenhouse Gas Emission: Philippine Setting}

In the Philippines, the sector with the highest percent change of greenhouse gas emissions from 1990 to 2000 is the energy sector accounting for $91 \%$, followed by industrial processes at $88 \%$. The transportation sector alone (under energy sector) accounted for the highest percentage change of greenhouse gas emission from 1990 to 2000 at 279\% (Table 1).

The projected trending of carbon dioxide emission intensity in the Philippines is shown in Figure 3. The CO2 emissions per GDP and per capita show an increasing trend of increase over the years. However, it can be observed that carbon dioxide emissions per gross domestic product (GDP) show a gradual downward slope. The other two important greenhouse gases, methane and nitrous oxides, show increasing pattern of emission intensity.

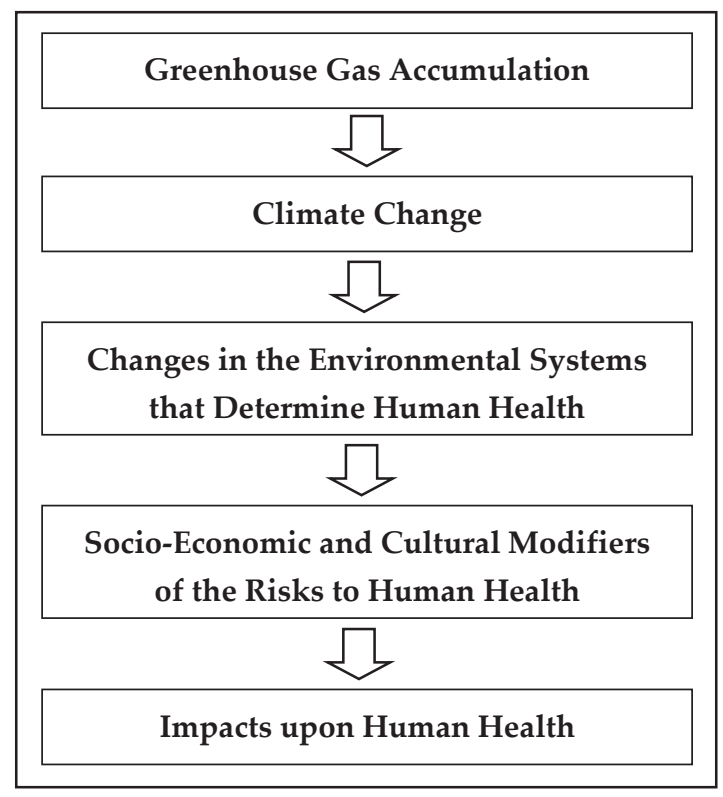

Figure 2. Schematic Diagram of Assessment of Health Impacts of Climate Change. Adapted from: WHO, 2000. ${ }^{14}$

Table 1. Greenhouse Gas Emissions by Sector in the Philippines

\begin{tabular}{|c|c|c|c|c|c|c|c|}
\hline \multirow{2}{*}{ Sector } & \multicolumn{2}{|c|}{1990} & \multicolumn{2}{|c|}{2000} & \multicolumn{2}{|c|}{2004} & \multirow[t]{2}{*}{ Change 1990-2000 } \\
\hline & $\mathrm{Mt} \mathrm{CO} 2$ & $\%$ & $\mathrm{Mt} \mathrm{CO} 2$ & $\%$ & $\mathrm{Mt} \mathrm{CO} 2$ & $\%$ & \\
\hline Energy & 36 & 30.4 & 68.9 & 40.6 & 72.6 & 91.8 & $91 \%$ \\
\hline Electricity \& Heat & 14.2 & 11.9 & 26.8 & 15.8 & 28.9 & 36.5 & $89 \%$ \\
\hline Manufacturing \& Construction & 8.3 & 7 & 9.2 & 5.4 & 11.2 & 14.1 & $11 \%$ \\
\hline Transportation & 6.2 & 5.2 & 23.5 & 13.9 & 25.4 & 32.1 & $279 \%$ \\
\hline Other fuel combustion & 7.4 & 6.2 & 9.4 & 5.5 & 6.8 & 8.6 & $27 \%$ \\
\hline Fugitive emissions & 0 & 0 & 0 & 0 & 0.3 & 0.4 & $0 \%$ \\
\hline Industrial processes & 3.2 & 2.7 & 6 & 3.5 & 6.5 & 8.2 & $88 \%$ \\
\hline Land use Change and Forestry & 79.4 & 66.9 & 94.9 & 55.9 & NA & NA & $20 \%$ \\
\hline Total & 118.6 & & 169.8 & & 79.1 & & $43 \%$ \\
\hline
\end{tabular}

Source: Climate Analysis Indicators Tool (CAIT), 2010.15 


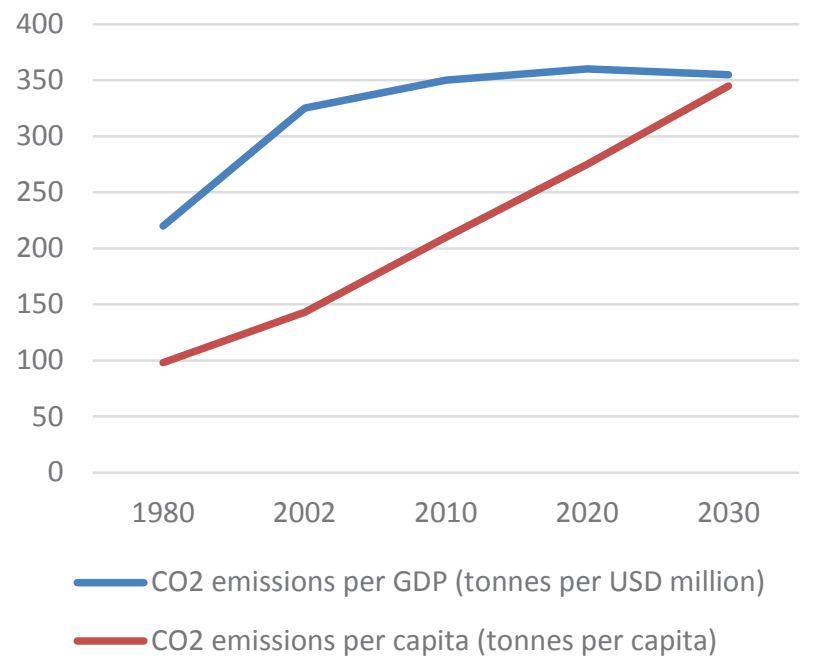

Source: APERC (2006)

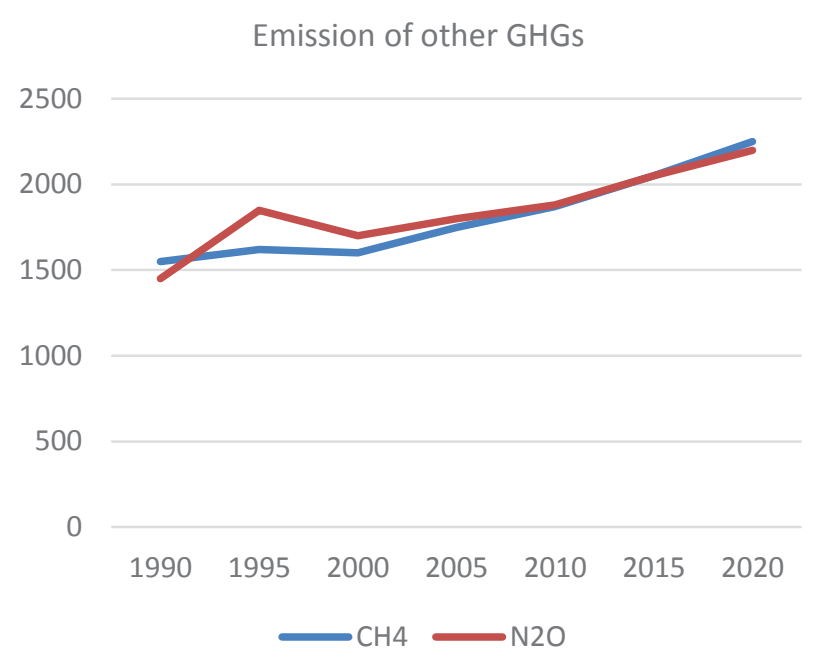

Source: EPA (2006)

Figure 3. Carbon dioxide and other Greenhouse Gases Emission Intensity in the Philippines.

Table 2. Diagrammatic Representation of Pathways Depicting How Climate Change Affects Human Health. Adapted from Haines, et al, 2004. ${ }^{17}$

\begin{tabular}{|c|c|c|c|c|}
\hline \multirow[t]{9}{*}{$\begin{array}{l}\text { Natural and Human } \\
\text { Influences }\end{array}$} & \multirow[t]{9}{*}{$\begin{array}{l}\text { Climate variability } \\
\text { and change }\end{array}$} & $\begin{array}{l}\text { Regional and local weather } \\
\text { change }\end{array}$ & $\begin{array}{l}\text { Change in intermediate } \\
\text { effects }\end{array}$ & Adverse health effects \\
\hline & & \multirow{6}{*}{$\begin{array}{l}\text { Extreme weather } \\
\text { precipitation temperature }\end{array}$} & None & Health related illnesses and deaths \\
\hline & & & & Extreme weather-related health effects \\
\hline & & & $\begin{array}{l}\text { Air pollution concentration } \\
\text { and distribution }\end{array}$ & Air pollution-related health effects \\
\hline & & & Pollen production & Allergic diseases \\
\hline & & & $\begin{array}{l}\text { Microbial contamination } \\
\text { and transmission }\end{array}$ & $\begin{array}{l}\text { Infectious diseases (water-borne, food-borne, } \\
\text { vector-borne and rodent-borne disease) }\end{array}$ \\
\hline & & & Crop yields & Malnutrition \\
\hline & & \multirow[t]{2}{*}{ Change in sea level } & Coastal flooding; & Storm-surge-related drowning ad injuries \\
\hline & & & Coastal aquifer salinity & Health problems of displaced populations \\
\hline
\end{tabular}

Table 3. Diagrammatic Representation of the Direct and Indirect Health Impacts of Climate Change. Adapted from Martens, $1998 .^{19}$

\begin{tabular}{|c|c|c|c|}
\hline \multirow[t]{7}{*}{ Climate change } & Direct & Thermal stress & Cardiovascular and respiratory morbidity and mortality \\
\hline & Indirect & Ecological mediation & \\
\hline & & Vector-borne diseases & Malaria, Dengue, Schistosomiasis \\
\hline & & Marine-borne diseases & Toxic algae and cholera \\
\hline & & Food productivity & Malnutrition \\
\hline & & Air pollution & Asthma and cardiorespiratory diseases \\
\hline & & Weather disasters sea-level rise & Deaths, injuries, damage to health infrastructure, increased risk of infectious diseases, conflicts \\
\hline
\end{tabular}

\section{Health Impacts of Climate Change}

Table 2 shows the epidemiologic framework in understanding the impact of climate change to overall human health, including both the immediate and secondary impacts. Immediate effects of climate change include extreme weather patterns and sea level rise. Secondary effects include changes in air pollution concentration and distribution causing pollution-related health effects, decreased agricultural productivity that may result in famine and malnutrition, pollen production that causes allergic syndromes, and microbial contamination and transmission that cause infectious diseases. ${ }^{16}$

Table 3 shows a diagrammatic representation of the direct and indirect health impacts of climate change as well as the various types of diseases that could develop. For instance, thermal stresses due to climate change could lead to cardiovascular and respiratory diseases. ${ }^{18}$

Table 4 summarizes the climate-related health impacts. The increased probability of climate change could result in an increased rate and incidence of corollary health impacts, whether direct or indirect, and short term or long term. 
Table 4. Climate-Related Health Impacts

\begin{tabular}{|c|c|c|}
\hline \multirow[t]{2}{*}{ Implications of Climate Change } & \multicolumn{2}{|c|}{ Potential Health Impacts } \\
\hline & Direct & Indirect \\
\hline$\uparrow$ exposure to thermal extremes & $\uparrow$ rates of heat- and cold- related deaths and illnesses & $\uparrow$ incidence and transmission of infectious diseases \\
\hline $\begin{array}{l}\uparrow \text { extreme weather events (intensity and } \\
\text { frequency) }\end{array}$ & $\begin{array}{l}\uparrow \text { frequency and severity of injuries, deaths, and } \\
\text { psychosocial disorders }\end{array}$ & - \\
\hline$\uparrow$ exposure to UV-B & $\begin{array}{l}\uparrow \text { risks of skin cancer, burns, infectious diseases, eye } \\
\text { damage (cataracts), immunosuppression }\end{array}$ & - \\
\hline $\begin{array}{l}\uparrow \text { range and activity of existing and new } \\
\text { infective agents (i.e., as foodborne, waterborne, } \\
\text { vector-and rodent-borne agents) }\end{array}$ & - & $\begin{array}{l}\uparrow \text { exposure to new and existing vector-borne } \\
\text { diseases; } \uparrow \text { incidence of diarrheal and other } \\
\text { infectious diseases; emergence of new diseases }\end{array}$ \\
\hline Sea-level rise & - & Psychosocial disruption \\
\hline $\begin{array}{l}\text { Worsened air pollution (contaminants, pollens } \\
\text { and spores) }\end{array}$ & - & $\begin{array}{l}\uparrow \text { incidence of respiratory diseases (i.e., asthma and } \\
\text { allergies) and cardiovascular diseases; } \\
\uparrow \text { exposure to environmental contaminants and } \\
\text { subsequent impacts to health development }\end{array}$ \\
\hline Agricultural Disruption & - & Malnutrition \\
\hline
\end{tabular}

*Based on the study of Furgal, et al. 2002; ${ }^{20} \uparrow=$ increased.

Adapted from Furgal, et al. 2006; ${ }^{21}$ Haines et, al. 2004; Woodward, et al. 1998.22

Table 5. Potential Health Impacts of Climate-Induced Extreme Weather Events

\begin{tabular}{|c|c|c|c|}
\hline Event & Type & Description & Potential Health Impact \\
\hline \multicolumn{4}{|c|}{ Above-average Rainfall } \\
\hline $\begin{array}{l}\text { Heavy } \\
\text { Precipitation event }\end{array}$ & Meteorological & “extreme event" & $\begin{array}{l}\text { Increased mosquito abundance or decreased if breeding sites are } \\
\text { washed away }\end{array}$ \\
\hline Flood & Hydrological & River/ stream over tops its banks & $\begin{array}{l}\text { Changes in mosquito abundance; contamination of surface water } \\
\text { with human or animal waste }\end{array}$ \\
\hline Flood & Social & Property or crops damaged & $\begin{array}{l}\text { Changes in mosquito abundance; contamination of water with faecal } \\
\text { matter and rodent urine (leptospirosis) }\end{array}$ \\
\hline Flood & $\begin{array}{l}\text { Catastrophic } \\
\text { flood or } \\
\text { "disaster" }\end{array}$ & $\begin{array}{l}\text { Flood leading to }>10 \text { killed, and/or } 200 \\
\text { affected, and/or government call for } \\
\text { external assistance. }\end{array}$ & $\begin{array}{l}\text { Changes in mosquito abundance; contamination of water with faecal } \\
\text { matter and rat urine and increased risk of respiratory and diarrhoeal } \\
\text { disease; deaths (drowning); injuries; health effects associated with } \\
\text { population displacement; loss of food supply; psychosocial impacts. }\end{array}$ \\
\hline \multicolumn{4}{|c|}{ Below-average Rainfall } \\
\hline Drought & Meteorological & $\begin{array}{l}\text { Evaporation exceeds water absorption; } \\
\text { soil moisture decreases }\end{array}$ & $\begin{array}{l}\text { Changes in vector abundance if, for example, vector breeds in dried } \\
\text { up river beds }\end{array}$ \\
\hline Drought & Agricultural & $\begin{array}{l}\text { Drier than normal conditions leading to } \\
\text { crop production }\end{array}$ & $\begin{array}{l}\text { Depends on socioeconomic factors, i.e., other sources of food are } \\
\text { available as well as the means to acquire them. }\end{array}$ \\
\hline Drought & Social & $\begin{array}{l}\text { Reduction in food supply or income, } \\
\text { reduction in water supply and quality }\end{array}$ & $\begin{array}{l}\text { Food shortage, illness, malnutrition, (increases risk of infection); } \\
\text { Increased risk of disease associated with lack of water for hygiene }\end{array}$ \\
\hline Drought & $\begin{array}{l}\text { Food Shortage/ } \\
\text { Famine/ Drought } \\
\text { disaster }\end{array}$ & $\begin{array}{l}\text { Food shortage leading to deaths; }>10 \\
\text { killed and/or } 200 \text { affected, or government } \\
\text { call for external assistance }\end{array}$ & $\begin{array}{l}\text { Deaths (starvation, infection); malnutrition and associated poor } \\
\text { health; stunting of physical and intellectual development of children; } \\
\text { health impacts associated with population displacement. }\end{array}$ \\
\hline
\end{tabular}

Adapted from: WHO, 2000;14 McMichael et. al., 2000. ${ }^{23}$

Table 6. List of Climate- Sensitive Vector-borne Diseases

\begin{tabular}{|c|c|c|c|}
\hline Major Diseases & Vector & Likelihood of Change with Climate Change & Present Distribution \\
\hline Malaria & Mosquito & +++ & Tropics and subtropics \\
\hline Dengue fever & Mosquito & ++ & All tropical countries \\
\hline Yellow fever & Mosquito & + & Tropical South America and Africa \\
\hline Filariasis & Mosquito & + & Tropics and Subtropics \\
\hline Leishmaniasis & Sandflies & ++ & Asia, southern Europe, Africa, Americas \\
\hline Chagas diseases & Triatomines & + & Central and South America \\
\hline African trypanosomiasis & Tsetse flies & + & Tropical Africa \\
\hline Onchocerciasis & Black flies & + & Africa, Latin America \\
\hline Schistosomiasis & Snails (intermediate host) & ++ & Tropics and subtropics \\
\hline
\end{tabular}

+ likely; ++ very likely; +++ highly likely.

Adapted from Haines et al. 20048 WHO, 2000. ${ }^{14}$ 


\section{Direct Health Impacts}

\section{Climate-Induced Extreme Weather Events}

Climate-induced extreme weather events such as heavy rainfall and various types of floods and droughts affect health of populations by contributing to changes in mosquito abundance as well as contamination of water sources with faecal matter. Notwithstanding the fact that catastrophic flood events can lead to deaths and injuries, and respiratory and diarrhoeal diseases. Droughts also cause food shortages and in turn, to widespread famine and starvation of communities (Table 5).

\section{Indirect Health Impacts}

Table 6 presents the climate-sensitive vector-borne diseases. It can be observed that malaria has the highest likelihood of incidence with climate change. Malaria is caused by a parasite that is transmitted by the bite of P. falciparum mosquitoes. Other diseases that are transmitted by mosquitoes are dengue fever, yellow fever, and filariasis. Since mosquitoes are the vectors of most of the climate-sensitive vector-borne diseases, it is suggested that climate sensitivity of mosquitoes and the transmission link of diseases brought about by this vector can be studied.

Table 7 presents the list of communicable diseases that have climate-epidemic relationship. Cholera and malaria show the highest association of disease outbreak with changes in climate. This was also reiterated in the study of $\mathrm{Xu}$, et al in $2014 .{ }^{24}$

\section{Data on Climate-Related Diseases Incidences in the Philippines}

Figure 4 shows the link between dengue cases and temperature change in the Philippines. Based on the graph, it is observed that as temperature increases, the number of cases of dengue also increases.

Figure 5 shows the link between malaria cases and temperature change. Similarly, the number of cases of malaria also increases with temperature increase.

Table 7. List of Communicable Diseases with Climate-Epidemic Relationship

\begin{tabular}{|c|c|c|c|c|c|}
\hline Disease & $\begin{array}{l}\text { Global Burden } \\
\text { (1000 DALYs) }\end{array}$ & Transmission & Distribution & Climate Epidemic Link & $\begin{array}{l}\text { Strength of } \\
\text { temporal climate } \\
\text { sensitivity }\end{array}$ \\
\hline Influenza & $\begin{array}{l}94603 \text { (all respiratory } \\
\text { infections- only a } \\
\text { fraction due to } \\
\text { influenza) }\end{array}$ & Air borne & Worldwide & $\begin{array}{l}\text { Decreases in temperature (winter) } \\
\text { associated with epidemics. A range of } \\
\text { human-related factors is more significant. }\end{array}$ & ++ \\
\hline Cholera & $\begin{array}{l}61966 \text { (including } \\
\text { diarrhoeal diseases) }\end{array}$ & $\begin{array}{l}\text { Food and water- } \\
\text { borne }\end{array}$ & $\begin{array}{l}\text { Africa, Asia, Russian } \\
\text { Federation, South } \\
\text { America }\end{array}$ & $\begin{array}{l}\text { Increases in sea and air temperatures as } \\
\text { well as El Niño events associated with } \\
\text { epidemics. Sanitation and human } \\
\text { behaviour are also important. }\end{array}$ & ++++ \\
\hline Malaria & 46486 & $\begin{array}{l}\text { Bite of female } \\
\text { Anopheles } \\
\text { mosquitoes }\end{array}$ & $\begin{array}{l}\text { Endemic in }>100 \\
\text { tropics and subtropics } \\
\text { countries and some } \\
\text { temperature areas }\end{array}$ & $\begin{array}{l}\text { Changes in temperatures and rainfall } \\
\text { associated with epidemics. Many other } \\
\text { locally relevant factors including vector } \\
\text { characteristics, immunity, population } \\
\text { movements, drug resistance, } \\
\text { environmental changes, etc. }\end{array}$ & +++++ \\
\hline $\begin{array}{l}\text { Meningococcal } \\
\text { meningitis }\end{array}$ & 6192 (all meningitis) & Air borne & Worldwide & $\begin{array}{l}\text { Increases in temperature and decreases in } \\
\text { humidity associated with epidemics. }\end{array}$ & ++ \\
\hline Dengue & 616 & $\begin{array}{l}\text { Bite of female } \\
\text { Aedes mosquitoes }\end{array}$ & $\begin{array}{l}\text { Africa, Europe, South } \\
\text { America, Southeast } \\
\text { Asia, Western Pacific }\end{array}$ & $\begin{array}{l}\text { High temperature, humidity, and rainfall } \\
\text { associated with epidemics in some areas. } \\
\text { Non-climatic factors also have an } \\
\text { important impact. }\end{array}$ & +++ \\
\hline $\begin{array}{l}\text { St. Louis } \\
\text { Encephalitis }\end{array}$ & NA & $\begin{array}{l}\text { Bite of female } \\
\text { Culex and Aedes } \\
\text { mosquitoes }\end{array}$ & $\begin{array}{l}\text { North and South } \\
\text { America }\end{array}$ & $\begin{array}{l}\text { High temperature and heavy rain } \\
\text { associated with epidemic. Reservoir } \\
\text { animal factors are also important. }\end{array}$ & ++ \\
\hline Rift Valley fever & Unquantified & $\begin{array}{l}\text { Bite of female } \\
\text { culicine } \\
\text { mosquitoes }\end{array}$ & Sub-Saharan Africa & $\begin{array}{l}\text { Heavy rains associated with onset of } \\
\text { epidemic. Cold weather associated with } \\
\text { end of epidemic. Reservoir animal factors } \\
\text { are also important. }\end{array}$ & +++ \\
\hline Ross River virus & Unquantified & $\begin{array}{l}\text { Bite of female } \\
\text { culicine } \\
\text { mosquitoes }\end{array}$ & $\begin{array}{l}\text { Australia and Pacific } \\
\text { islands }\end{array}$ & $\begin{array}{l}\text { High temperature and heavy precipitation } \\
\text { associated with onset of epidemic. Host } \\
\text { immune factors and reservoir animals are } \\
\text { also important factors. }\end{array}$ & +++ \\
\hline $\begin{array}{l}\text { Murray Valley } \\
\text { fever }\end{array}$ & Unquantified & $\begin{array}{l}\text { Bite of female } \\
\text { Culex mosquitoes }\end{array}$ & Australia & $\begin{array}{l}\text { Heavy rains and below average } \\
\text { atmospheric pressure associated with } \\
\text { epidemics. }\end{array}$ & ++ \\
\hline
\end{tabular}

+ Climate link is very weak ++ Climate plays a moderate role +++ Climate plays a significant role ++++ Climate is an important factor +++++ Climate is the primary factor in determining at least some epidemics, and the strength of the association between climate and disease outbreaks has been assessed on the basis of published quantitative (statistical) rather than anecdotal evidence. Adapted from Kuhn et al, 200525 
Dengue Fever Cases Philippines, 1992-2005

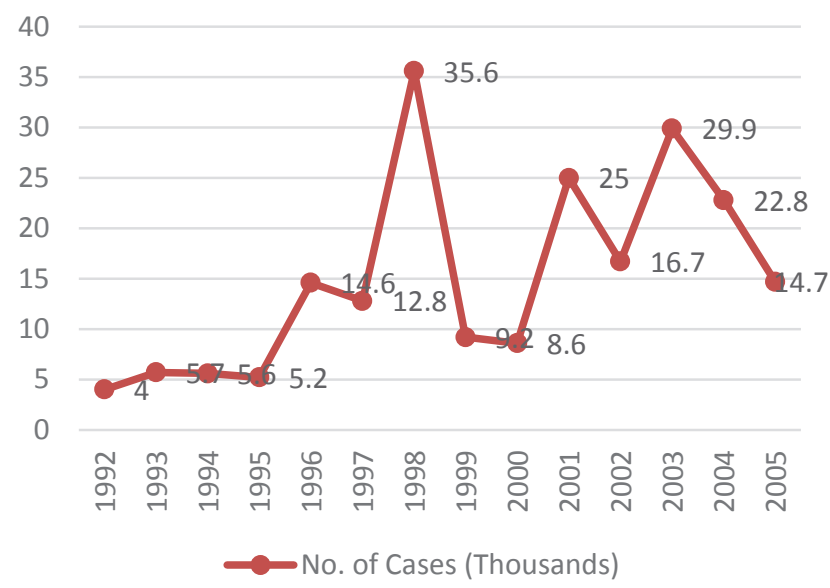

Figure 4. Relation of Dengue Cases and Temperature Change in the Philippines. Adapted from Perez, 2009.26

Malaria Cases in the Philippines: 1995-2005

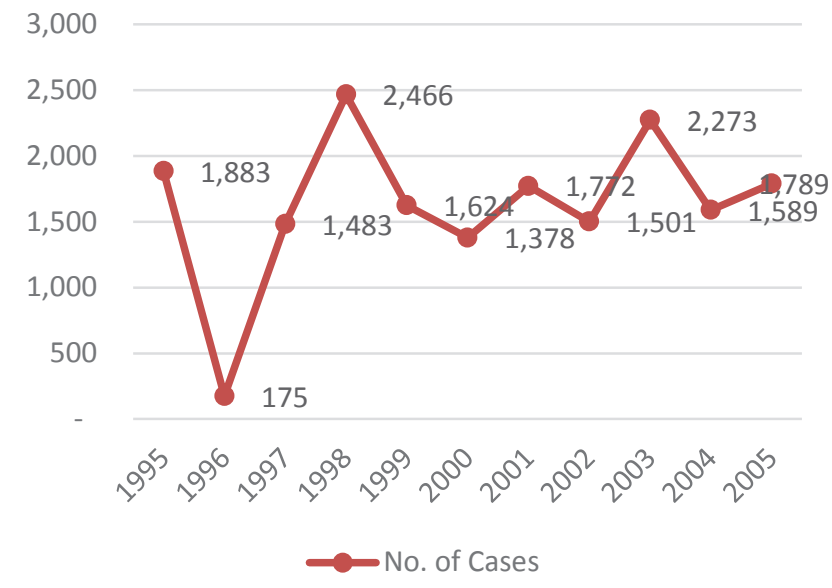

Figure 5. Relation of Malaria Cases and Temperature Change in the Philippines. Adapted from Perez, 2009.26

\section{Discussion}

At the advent of industrial revolution, increasing fossil fuel use, deforestation, irrigated agriculture, animal husbandry, among others have been associated with the increase in the concentration of atmospheric greenhouse gases (Haines, et al, 2000), resulting in an unprecedented variability of climate. ${ }^{27}$ Indeed, the global climate temperature is linked to human activities. ${ }^{8}$

The largest contributor to build up of greenhouse gases comes from human-generated activities such as land use planning, transportation systems and infrastructure, building construction and operation. The greenhouse gases that are produced from various agricultural and industrial activities include carbon dioxide, methane, and nitrous oxide. Of the three main gases, carbon dioxide has the greatest contribution to global warming. ${ }^{28}$ Carbon dioxide comes from combustion of fossil fuel and solid waste, cement manufacturing and steel and iron production. Methane comes from landfills, enteric fermentation, and coal mining. Nitrous oxide comes primarily from agricultural soil and mobile combustion. Examples of agricultural activities are applications of nitrogenous fertilizers, enteric fermentation, manure management, agricultural soil management, and field burning. ${ }^{28}$

\section{Link between Climate Change, Environmental Pollutants, and Incidence of Diseases}

Climate change also has a significant impact on air pollutants. Air-borne pollutants such as carbon dioxide, carbon monoxide, methane, nitrogen oxide, and sulfur dioxide contribute to the warming of global temperature. ${ }^{29}$ Warmer temperatures increase the presence of secondary air pollutants such as ozone and particulates in the atmosphere. According to Martens et al., ${ }^{19}$ air pollutants can aggravate allergic and cardio-respiratory illnesses. ${ }^{2}$

Table 8 presents a study of the Department of Health $(\mathrm{DOH})$ on the impact of air pollution to the public health of Metro Manila. The data show the effect of air pollutants to human health such as respiratory and cardiovascular diseases.

Table 8. Air Pollution Impacts on Public Health of Metro Manila $^{30}$

\begin{tabular}{ll}
\hline Morbidity & Mortality \\
\hline 10,000 excess cases of acute bronchitis & $\begin{array}{l}40-200 \text { persons due to } \\
\text { cardiovascular causes } \\
300-330 \text { persons due to } \\
300 \text { excess cases of asthma }\end{array}$ \\
$\begin{array}{l}\text { respiratory causes } \\
9 \text { excess cases of chronic bronchitis }\end{array}$ \\
\hline
\end{tabular}

Climate change can affect health in several pathways. These pathways can be through 1) increased frequency and intensity of heat waves; 2) increased floods and droughts; 3) changes in the distribution of vector-borne diseases; and 4) risks of disasters and malnutrition. ${ }^{17}$ There are several diseases that can be impacted by climate change. These are insect and rodent borne diseases (e.g., dengue, leptospirosis, and malaria), water-borne diseases (e.g., schistosomiasis, cholera), food-borne diseases (e.g., diarrhoeal diseases and typhoid), respiratory diseases (e.g., asthma, bronchitis, and respiratory allergies and infections), and heat-related illnesses (e.g., sunstroke, sunburn, heat stress or exhaustion, dehydration). ${ }^{13}$

The study of Ebi in 2008 showed the correlation of various diseases with indicators of climate change. His study was conducted in five provinces and one city in the Philippines. ${ }^{31}$ The study showed that diarrhea and malaria are most affected by climate change while diseases such as tuberculosis, meningococcemia, tetanus, chicken pox, influenza, bronchitis, pneumonia, nutritional deficiencies, malignant neoplasms (cancer) and mumps had the higher percent correlation with the climate change. In another study, 
pneumonia, whooping cough, hepatitis, diarrhea, dengue, cholera and viral encephalitis have $30-50 \%$ correlation. ${ }^{31}$

The potential health impacts of climate change are classified into two: the direct and indirect health impacts. The direct impact includes thermal stresses and weather disasters that result in immediate serious illnesses, injuries, and deaths. Indirect health impacts occur via the link of change in the transmission of infectious diseases, contamination and scarcity of water supply, and food insecurity. $., 22,32$

Heat stroke is another problem that is associated with increase in temperature. An individual who is exposed to extreme and prolonged heat may experience heat stress, and death may ensue. Heatstroke is the most common health condition associated to heat. ${ }^{33}$

\section{Change in the Transmission Patterns of Diseases}

The indirect effects of climate change to human health occur through ecological alterations which in turn, affects food production, safety of sources of drinking water, and transmission patterns of diseases.

For disease transmission, most vector-borne diseases are weather sensitive. Climatic factors influence the ecology, development, behaviour, and survival of vectors and hosts thus affecting the transmission patterns of diseases. Transmission rates and patterns and spread of vector-borne and rodent-borne diseases generally increase with global warming. ${ }^{3}$ Ecology, reproduction, parasite development, behaviour, bite frequency, and survival of vectors of various diseases also increase with rising temperature, consequently, affecting disease infection. For instance, in a study in east African highlands, it was found that there was ten-fold increase in mosquito abundance with every unit increase in temperature. In fact, Epstein 2005 noted that the resurgence and redistribution of infections involving vectors, hosts, and reservoirs -mosquitoes, ticks, and rodents- are good indicators of climate change. The two most important vectorborne diseases in tropics and subtropics are malaria and dengue fever. ${ }^{34-35}$ Malaria is the currently most widespread and serious vector-borne disease in the world. On the other hand, leptospirosis is the most widespread zoonotic disease in the world. Increasing temperature affects range of malarial transmissibility and outbreaks. Malaria cases were also found to increase with increasing temperature in the study in Kenya. ${ }^{3}$

The geographic distribution of insects is highly sensitive to temperature changes. ${ }^{36}$ Usually after heavy rainfall, there increase in epidemics/outbreaks of diseases. ${ }^{37}$ Outbreaks of leptospirosis, for instance, occur after extreme flooding or hurricane. Breeding sites of mosquitoes are created along roadways and in dirty receptacles after heavy rains. ${ }^{23}$ Drought increases the infectivity of mosquitoes since warmer temperature speeds up the malarial parasite inside the mosquitoes. ${ }^{38}$ (Table 9) Water-borne diseases are also on the rise with increased sea surface temperature and sea level rise. ${ }^{8,39}$ In developing countries, heavy rainfall contributes to the contamination of underground water sources and surface water due to flooding, hence, coliform regrowth is expected to increase in water distribution systems. ${ }^{40}$

Table 9. Climate Change Affecting Disease Transmission ${ }^{8}$

\begin{tabular}{l}
\hline How Climate Change Affect Diseases Transmission \\
\hline Shifting of the vector's geographic range \\
Increasing reproductive and biting rates \\
Shortening the pathogen incubation period
\end{tabular}

\section{Decreased Food Production}

Climate change has implications on food production as well (8) due to variations in temperature and moisture. These two environmental parameters are significant factors in germination, growth, and photosynthesis of crops. If these parameters are altered, agricultural productivity may be affected. Plant diseases, predator-pest relationships, and water supply are also the other factors that may be triggered by climate change, which in turn, affect crop production. ${ }^{8,19}$ Famine, as noted by Kovats et al. occurs when there is climate stress on agriculture. ${ }^{27}$ Table 10 shows how climate change affects food production. Poor health and lack of hygiene due to limited water and food supply can further result in water-borne and diarrheal diseases.

Table 10. Climate Change Affecting Food Production

\begin{tabular}{l}
\hline Ways on How Climate Change Could Affect Food Production \\
\hline Geographical shifts and yield changes in agriculture \\
Reduction in the quantity of water available for irrigation \\
Loss of land through rising sea level \\
Loss of land through rising sea level and the associated salinization \\
Effects on fisheries productivity through rising sea level and changes in \\
water temperatures, currents, freshwater flows and nutrient circulation.
\end{tabular}

\section{Conclusion}

Climate science is a wide-ranging discipline of study and research. Merely looking at the health impacts of climate change requires interdisciplinary integration of both the environmental and health sciences.

This review has discussed the impact of climate change on human health. First, climate change which is a result of increased concentrations greenhouse gases in interaction chemically and physically with air-borne pollutants can cause various cardio-respiratory diseases. Second, direct health impacts of climate change attributed to climateinduced natural disasters cause increased rates of mortality and morbidity. Lastly, indirect health impacts of climate change due to ecological alterations (i.e., change in transmission patterns of vectors of infectious diseases, change in agricultural productivity, and contamination of water sources) can lead to malnutrition and increased incidences of certain diseases. As the worldwide global climate continuously changes, the Philippines will be 
continually affected with climate variability, and human health toll likewise increases.

\section{References}

1. Huynen MMTE, Martens P, Akin S-M. Climate change: an amplifier of existing health risks in developing countries. Environ Dev Sustain. 2013; 15(6):1425-42.

2. Intergovernmental Panel on Climate Change (IPCC). Climate Change 2007: Impacts, Adaptation, and Vulnerability. Contribution of Working Group II to the Fourth Assessment Report of the Intergovernmental Panel on Climate Change. Parry ML, Canziani OF, Palutikof JP, van der Linden PJ, Hanson CE, eds. Cambridge, United Kingdom: Cambridge University Press; 2007. pp. 1000.

3. Costello A, Abbas M, Allen A, et al. Managing the health effects of climate change. Lancet. 2009; 373(9676):1693-733.

4. Patz JA, Epstein PR, Burke TA, Balbus JM. Global climate change and emerging infectious diseases. JAMA. 1996; 275(3):217-23.

5. Aron JL, Corvalan CF, Philippeaux H. Climate variability and change and their health effects in the Caribbean: Information for adaptation planning in the health sector. Conference 21-22 May 2002; workshop 2325 May 2002. Geneva:World Health Organization. 2003.

6. Beggs PJ. Impacts of Climate Change on aeroallergens: past and future. Clin Exp Allergy. 2004; 34(10):1507-13.

7. Bernard SM, Samet JM, Grambsch A, Ebi KL, Romieu I. The potential impacts of climate variability and change on air pollution-related health effects in the United States. Environ Health Perspect. 2001; 109 (Suppl 2):199-209.

8. Haines A, Patz JA. Health effects of climate change. JAMA. 2004; 291(1):99-103.

9. Knowlton K, Rosenthal JE, Hogrefe C, et al. Assessing ozone-related health impacts under a changing climate. Environ Health Perspect. 2004; 112(15):1557-1563.

10. McMichael AJ, Kovats RS, Martens P. Climate change and human health: final report to the Department of Environment, Transport and the Regions. London School of Hygiene and Tropical Medicine/ICIS, London/Maastricht. 2000.

11. Bytnerwicz A, Fenn ME, Glaubig R. Dry deposition of nitrogen and sulfur to forest canopies at three plots (calculated on the basis of foliage rinsing, internal uptake of gaseous pollutants and estimates of deposition to ground). Assessment of acidic deposition and ozone effects on conifer forests in the San Bernardino Mountains. Final report to the California Air Resources Board, Contract No. A032-180; 1996. 4-1 -4-75.

12. Oreskes N. Beyond the ivory tower: the scientific consensus on climate change. Science. 2004; 306(5702):1686.

13. IPCC, 2014: Summary for policymakers. In: Climate Change 2014: Impacts, Adaptation, and Vulnerability.Part A: Global and Sectoral Aspects. Contribution of Working Group II to the Fifth Assessment Report of the Intergovernmental Panel on Climate Change [Field, C.B., V.R. Barros, D.J. Dokken, K.J. Mach, M.D. Mastrandrea,T.E. Bilir, M. Chatterjee, K.L. Ebi, Y.O. Estrada, R.C. Genova, B. Girma, E.S. Kissel, A.N. Levy, S. MacCracken,P.R. Mastrandrea, and L.L. White (eds.)]. Cambridge University Press, Cambridge, United Kingdom and NewYork, NY, USA, pp. 1-32.

14. World Health Organization (WHO). 2000. Climate Change and Human Health. Impact and Adaptation. [Online]. 2012 . Available from http://www.who.int/globalchange/publications/reports/en/index.html

15. Climate Analysis Indicators Tool (CAIT). Washington, DC: World Resources Institute. [Online]. 2010 [cited 2011]. Available from http://cait.wri.org/.

16. Austin S, Ford J, Berrang-Ford L, Araos, M, Parketr S, Fleury MD. Public health adaptation to climate change in Canadian jurisdictions. Int J Environ Res Public Health. 2015; 12(1):623-51.

17. Haines A, Patz J. Health effects of climate change. JAMA. 2004; 291(1):99-103.

18. Fan J, Wei W, Bai Z, et al. A systematic review and meta-analysis of dengue risk with temperature change. Int J Environ Res Public Health. 2014; 12(1):1-15.
19. Martens W. Health Impacts of Climate Change and Ozone Depletion An eco-epidemiological modelling approach. Environ Health Perspect. 1998; 106 (suppl 1):241-51.

20. Furgal C, Martin D, Gosselin P. Climate change and health in Nunavik and Laborador: lessons from Inuit knowledge. In: Krupnik I, Jolly D, eds. The Earth is Faster Now: Indigenous Observations of Arctic Environmental Change. Washington, DC: Arctic Research Consortium of the United States, Arctic Studies Centre, Smithsonian Institute; 2002. pp. 266-300.

21. Furgal C, Seguin J. Climate change, health, and vulnerability in Canadian northern aboriginal communities. Environ Health Perspect. 2006; 114(12):1964-70

22. Woodward A, Hales S, Weinstein P. Climate change and human health in the Asia Pacific region: who will be most vulnerable? 1998; Clim Res. 11:31-8

23. Kovats RS, Menne B, Ahern MJ, Patz JA. National assessments of health impacts of climate change: a review. In: McMichael AJ, et al., eds. Climate change and human health: risks and responses. Geneva: WHO/World Meteorological Organization/ United Nations Environment Programme; 2003. pp. 181-203.

24. Xu M, Cao C, Wang D, Kan B. Identifying environmental risk factors of cholera in a coastal area with geospatial technologies. Int J Environ Res Public Health; 2014; 12(1):54-70.

25. Kuhn K, Campbell-Lendrum D, Haines A, Cox J. Using climate to predict infectious disease epidemics. Geneva: WHO. 2005

26. Perez RT. Climate Change in the Philippines. Presented at Symposium on the Economics of Climate Change in SE Asia. De La Salle University. 2009.

27. Kovats RS, Edwards S, Hajat S, Ebi KL. Environmental temperature and foodborne disease: time series analysis in European countries. Epidemiology. 2003; 14:S15-16.

28. Johnson JM, Franzluebbers AJ, Weyers SL, Reicosky DC. 2007 Agricultural opportunities to mitigate greenhouse gas emissions. Environ Pollut. 2007; 150(1);107-24.

29. Zhang J, Smith KR, Ma Y, et al. Greenhouse gases and other airborne pollutants from household stoves in China: a database for emission factors. Atmos Environ. 2000; (34):4537-49.

30. Department of Health (DOH). In Asian Development Bank. Country Synthesis Report on Urban Air Quality Management [Online]. 2006. Available from http://www.adb.org/Documents/Reports/Urban-AirQuality-Management/philippines.pdf.

31. Ebi KL. Adaptation costs for climate change-related cases of diarrhoeal disease, malnutrition, and malaria in 2030. GlobalHealth. 2008; 4:9.

32. Wang Y, Rao Y, Wu X, Zhao H, Chen J. A method for screening climate change-sensitive infectious diseases. Int J Environ Res Public Health. 2015; 12(1):767-83.

33. McGeehin MA, Mirabelli M. The potential impacts of climate variability and change on temperature-related morbidity and mortality in the United States. Environ Health Perspect. 2001; 109(suppl 2):185-9.

34. Fan J, Wei W, Bai Z, et al. A systematic review and meta-analysis of dengue risk with temperature change. Int J Environ Res Public Health. 2014; 12(1):1-15.

35. Githeko AK, Lindsay SW, Confalonieri UE, Patz JA. Climate change and vector-borne diseases: a regional analysis. Bull World Health Organ. 2000; 78(9):1136-47.

36. Klich M, Lankester MW, Wu KW. Spring migratory birds (Aves) extend the northern occurrence of blacklegged tick (Acari: Ixodidae). J Med Entomol. 1996; 33(4):581-5.

37. Gubler DJ, Reiter P, Ebi KL, Yap W, Nasci R, Patz JA. Climate Variability and Change in the United States: Potential Impacts on Vector-and RodentBorne Diseases. Environ Health Perspect. 2001; 109(suppl 2):223-33.

38. Harvard Medical School. Extreme Weather Events: The Health and Economic Consequences of the 1997/98 El Niño and La Niña. Boston: The Center for Health and the Global Environment. Harvard Medical School. 1999.

39. Davies G, Mclver L, Kim Y, Hashizume M, Iddings S, Chan V. Waterborne diseases and extreme weather events in Cambodia: review of impacts and implications of climate change. Int J Environ Res Public Health. 2015; 12(1):191-213.

40. Hunter PR. Climate change and waterborne and vector-borne disease. J Appl Microbiol. 94 Suppl:37S-46S. 